\title{
Helicobacter pylori Colonization Drives Urokinase Receptor (uPAR) Expression in Murine Gastric Epithelium During Early Pathogenesis
}

\author{
Warner Alpízar-Alpízar 1,2,3,*iD, Mette E. Skindersoe ${ }^{4,5}$, Lone Rasmussen ${ }^{6}$, \\ Mette C. Kriegbaum 1,2, Ib J. Christensen 1,2,7, Ida K. Lund 1,2, Martin Illemann 1,2, \\ Ole D. Laerum ${ }^{1,2}$, Karen A. Krogfelt ${ }^{4,8,9} \mathbb{D}^{\mathbb{D}}$, Leif P. Andersen ${ }^{6}$ and Michael Ploug ${ }^{1,2, *(D)}$ \\ 1 The Finsen Laboratory, Rigshospitalet, 2100 Copenhagen, Denmark; \\ mette.kriegbaum@hotmail.com (M.C.K.); ib.jarle.christensen@regionh.dk (I.J.C); \\ ik_lund@hotmail.com (I.K.L.); martinillemann@yahoo.com (M.I.); ole.larum@uib.no (O.D.L.) \\ 3 Centre for Research on Microscopic Structures (CIEMic) and Department of Biochemistry, University of \\ Costa Rica, 2060 San José, Costa Rica \\ 4 Department of Bacteria, Parasites and Fungi, Statens Serum Institute, 2300 Copenhagen, Denmark; \\ mskindersoe@gmail.com (M.E.S.); kak@ssi.dk (K.A.K.) \\ 5 Bacthera, Kogle Allé 6, 2970 Hoersholm, Denmark \\ 6 Department of Clinical Microbiology, Rigshospitalet, 2100 Copenhagen, Denmark; \\ leifpercivalandersen@outlook.dk (L.P.A.); lone@jth.dk (L.R.) \\ 7 Hvidovre Hospital, University of Copenhagen, 2650 Copenhagen, Denmark \\ 8 Department of Science and Environment, Roskilde University, 4000 Roskilde, Denmark \\ 9 Department of Virus and microbiological Diagnostics, Statens Serum Institute, 2300 Copenhagen, Denmark \\ * Correspondence: warner.alpizar@ucr.ac.cr (W.A.-A.); m-ploug@finsenlab.dk (M.P.)
}

Received: 10 June 2020; Accepted: 7 July 2020; Published: 9 July 2020

check for updates

\begin{abstract}
Background: Persistent Helicobacter pylori infection is the most important risk factor for gastric cancer. The urokinase receptor (uPAR) is upregulated in lesions harboring cancer invasion and inflammation. Circumstantial evidence tends to correlate H. pylori colonization with increased UPAR expression in the human gastric epithelium, but a direct causative link has not yet been established in vivo; (2) Methods: In a mouse model of $H$. pylori-induced gastritis, we investigated the temporal emergence of UPAR protein expression in the gastric mucosa in response to $H$. pylori (SS1 strain) infection; (3) Results: We observed intense UPAR immunoreactivity in foveolar epithelial cells of the gastric corpus due to de novo synthesis, compared to non-infected animals. This uPAR induction represents a very early response, but it increases progressively over time as do infiltrating immune cells. Eradication of $H$. pylori infection by antimicrobial therapy causes a regression of uPAR expression to its physiological baseline levels. Suppression of the inflammatory response by prostaglandin $\mathrm{E}_{2}$ treatment attenuates uPAR expression. Notwithstanding this relationship, $H$. pylori does induce UPAR expression in vitro in co-cultures with gastric cancer cell lines; (4) Conclusions: We showed that persistent $H$. pylori colonization is a necessary event for the emergence of a relatively high uPAR protein expression in murine gastric epithelial cells.
\end{abstract}

Keywords: uPAR; Helicobacter pylori; gastric cancer; gastritis; mucous metaplasia; mouse model

\section{Introduction}

Gastric cancer is the final clinical endpoint of a stepwise process in which Helicobacter pylori infection plays a central role [1,2]. Other gastric pathologies associated with $H$. pylori infection include 
peptic ulcer disease and mucosa-associated lymphoid tissue (MALT) lymphomas [3]. This bacterial infection has also been inversely associated with a range of extra-gastric systemic manifestations, including asthma and allergies [4,5]. The infection is usually established early in life and persists lifelong in the absence of treatment. This leads to a sustained chronic inflammation characterized by infiltration of inflammatory cells in the gastric mucosa and expression of inflammatory mediators by immune and epithelial cells [6,7]. Certain $H$. pylori strains are associated with a higher risk of gastric cancer, in particular those that carry specific virulence factors, such as the vacuolating cytotoxin (VacA) and cytotoxin-associated gene A (CagA) [8]. The combination of bacterial factors, host immune response, and environmental insults drives the initiation and progression from mucosal atrophy, intestinal metaplasia, and dysplasia towards gastric cancer-a stepwise process known as the Correa cascade $[1,9]$. How $H$. pylori and its virulence factors interfere with the physiological processes as well as the biological mechanisms determining the final outcome remain largely unknown.

Extravascular activation of plasminogen is controlled by the urokinase-type plasminogen activator (uPA), its receptor (uPAR), its inhibitor PAI-1, and $\alpha_{2}$-antiplasmin [10]. Besides degrading major extracellular matrix proteins (e.g., fibrin), the generated plasmin also releases latent growth factors sequestered in the matrix [8]. Several studies correlate uPAR expression in cancer lesions with invasive and metastatic disease, and levels of shed soluble uPAR in plasma correlate accordingly with cancer patient survival in various types of cancer, including gastric cancer [11-13]. Mechanistic studies have shown that overexpression of UPAR in tumor cells confers enhanced proliferative, inva-sive, and metastatic potential through the interaction of uPAR with integrins and fibronectin [14-18]. Large research efforts are currently being devoted to the development of a non-invasive imaging platform for uPAR expression by positron emission tomography with a high clinical translational potential [19-21]. Recently, uPAR emerged as a cell-surface protein induced during senescence and a potential target for chimeric antigen receptor (CAR) T cell-based therapy for senescence-associated diseases [22].

Accumulating experimental evidence tends to implicate H. pylori in the induction of uPAR expression both in vitro and in vivo. Global gene-profiling studies highlight uPAR as one of the top upregulated genes in AGS and T84 cell lines, when co-cultured with H. pylori [23-26]. Clinical studies show increased global uPAR mRNA levels in biopsies of the gastric corpus of $H$. pylori-infected patients [27]. In general, studies on global mRNA expression levels nonetheless often lack information on histological confinement of the expression and furthermore have the inherent caveat that mRNA levels rarely correlate with actual protein levels [28]. We reported a correlation between uPAR protein expression in foveolar epithelial cells and the presence of $H$. pylori in human gastric mucosa [29]. Nevertheless, de novo synthesis of uPAR protein in the gastric epithelium in response to a $H$. pylori challenge has, to the best of our knowledge, never been systematically studied in vivo. The present study aimed to establish the in vivo kinetics of uPAR induction in the gastric mucosa in response to $H$. pylori infection and to explore the correlation to inflammation and gastric pathology in a mouse model of $H$. pylori-induced gastritis. We now demonstrate that sustained H. pylori colonization of the gastric mucosa is a necessary event for the induction of relatively high uPAR protein expression. The functional implications of our finding need to be further investigated given the central role of UPAR in cancer biology, and the circumstantial evidence from mouse models of pulmonary infections implicating uPAR in the host clearance of the causative bacterial pathogens [30-33].

\section{Material and Methods}

\subsection{Ethics Statement}

All murine experiments included in this study were carried out in accordance with the principles of the Basel Declaration and recommendations of the Danish Animal Experiments Inspectorate and the Department of Experimental Medicine (AEM). The protocol was approved by the Danish Animal Experiments Inspectorate and the AEM (permission number: 2010/561-1394 and project number: P12-165, respectively). 


\subsection{Mice}

Five- to six-week-old female pathogen-free C57BL/6 mice were obtained from Taconic (Silkeborg, Denmark) and housed under specific pathogen-free conditions (including H. pylori and other Helicobacter species) at the Animal Facility of the AEM, University of Copenhagen. Mice were offered sterile autoclaved food (Laboratory Autoclavable Rodent Diet 5010, Code: 0001326, LabDiet) and water ad libitum. Mice enrolled in the experiments were between 6 and 8 weeks old and were moved to an experimental section before they were inoculated with $H$. pylori. Of note, the animal facility has a thorough monitoring program to check for pathogens.

\subsection{H. pylori Culture and Experimental Infections}

Two H. pylori strains, SS1 (mouse-adapted $\operatorname{cag} A+$, vacA+ strain with no functionality of the cag pathogenicity island (cag PAI)) and $\mathrm{J} 99(\operatorname{cag} A+, v a c A+)$, were grown on chocolate agar plates at $37^{\circ} \mathrm{C}$ under microaerobic conditions $\left(5 \% \mathrm{O}_{2}, 10 \% \mathrm{CO}_{2}\right.$, and $\left.85 \% \mathrm{~N}_{2}\right)$. Forty-eight hours after the first sub-cultivation, the SS1 strain was harvested and suspended in $0.85 \%(w / v) \mathrm{NaCl}$ Medium (bioMérieux, Marcy l'Etoile, France) and adjusted to a McFarland turbidity standard of $3\left(\approx 10^{8} \mathrm{CFU} / \mathrm{mL}\right)$. Mice were inoculated with a single dose of approximately $10^{8}$ bacteria (CFU) in $0.2 \mathrm{~mL}$ of $0.85 \% \mathrm{NaCl}$ by oral gavage (20G, 3.8-cm disposable animal feeding needles, Code: 01-208-87, Fisher Scientific, Waltham, MA, United States). Control mice received $0.2 \mathrm{~mL}$ of saline (Figure 1 ).

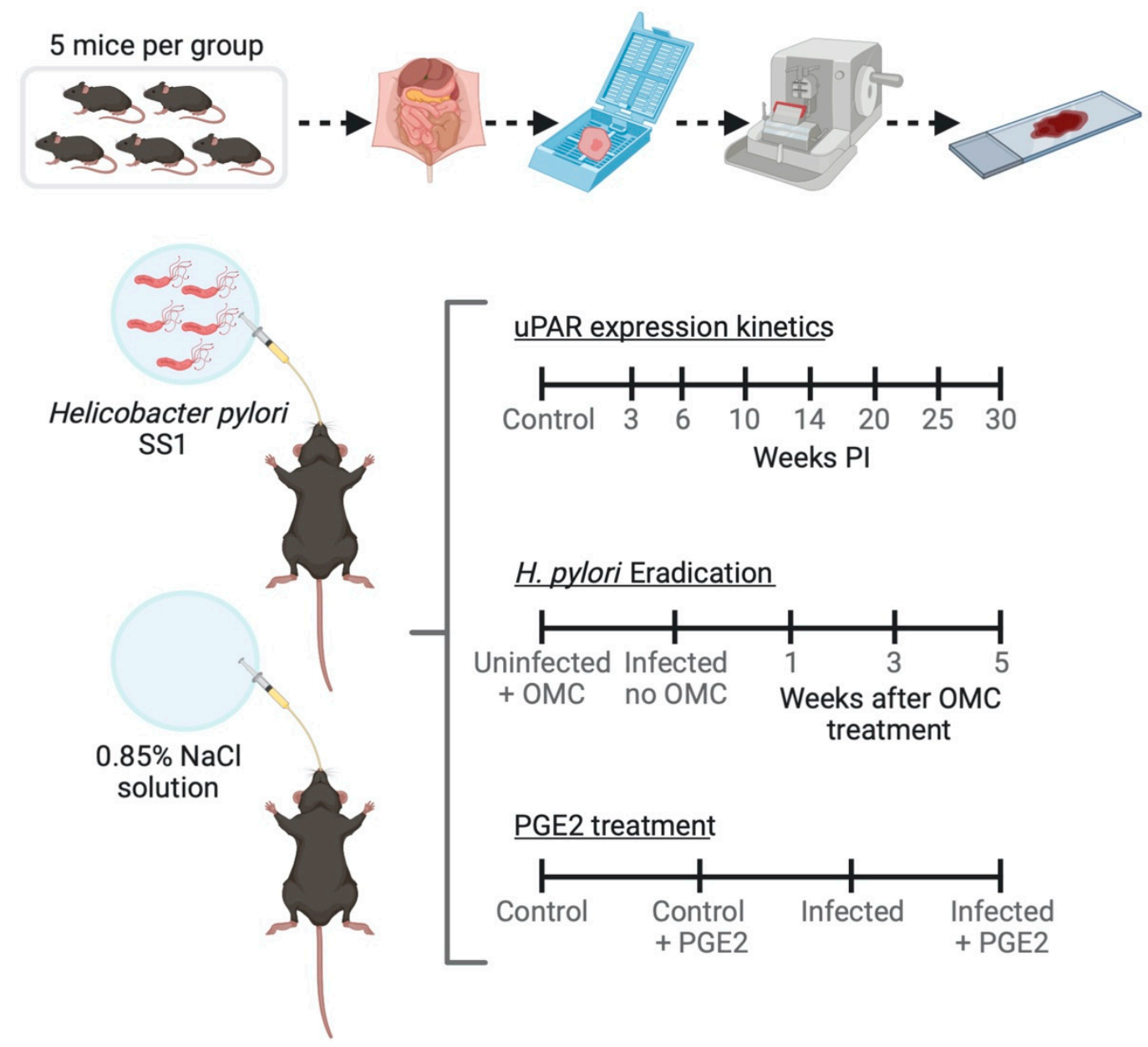

Figure 1. Schematic view of the experiments performed on a mouse model of Helicobacter pylori-induced gastritis. OMC; omeprazole, metronidazole, clarithromycin; PGE2; Prostaglandin $\mathrm{E}_{2}$ (created with BioRender.com). 


\subsection{Antimicrobial Therapy for H. pylori Eradication in Mice}

Fourteen weeks post-inoculation (PI), animals ( $n=5$ mice per experimental group) received antimicrobial therapy against $H$. pylori consisting of Omeprazole (400 $\mu \mathrm{mol} / \mathrm{kg} / \mathrm{day}$; Sigma Aldrich, Søborg, Denmark), Metronidazole (14.2 mg/kg/day; Baxter, Søborg, Denmark), and Clarithromycin (7.15 mg/kg/day; Sigma Aldrich, Søborg, Denmark) once a day for 7 days (Figure 1). A similar antimicrobial therapy has been used successfully to eradicate H. pylori from experimentally infected mice [34,35]. Stocks and working dilutions were prepared as described [35].

\subsection{Pharmacological Treatment of Mice with Prostaglandin $E_{2}\left(P G E_{2}\right)$ Analogs}

Five day PI animals ( $n=5$ mice per experimental group) were treated with a mixture of 16,16-dimethyl PGE 2 and 17-phenyl trinor PGE 2 (Cayman Chemical, Ann Arbor, MI, USA) or with phosphate-buffered saline (PBS) for 14 weeks by dosing twice intraperitoneally (i.p.) and once combined i.p./orally per week (Figure 1) as described [36]. Doses of $30 \mu \mathrm{g} /$ week/mouse of the mixture of PGE 2 analogs were administered [36].

\subsection{Resection and Processing of Gastric Tissue for Histology}

For the isolation of stomach tissue, mice were initially anaesthetized by i.p. injection of $0.1 \mathrm{~mL} / 10 \mathrm{~g}$ of a 1:1 mixture of Dormicum (Midazolam $5 \mathrm{mg} / \mathrm{mL}$ ) and Hypnorm (Fluanison $5 \mathrm{mg} / \mathrm{mL}$ and Fentanyl $0.1 \mathrm{mg} / \mathrm{mL}$ ), and subsequently perfused with cold PBS, followed by perfusion with $4 \%$ paraformaldehyde in PBS. Resected stomachs were opened along the greater curvature, washed with PBS, and cut longitudinally into four stripes, extending from the squamous forestomach through the duodenum. These stripes were fixed overnight in $4 \%$ paraformaldehyde and paraffin embedded. Then, $3-\mu m$ tissue sections were deparaffinized in xylene and hydrated in a gradual series of ethanol-water dilutions. Sections were stained either with hematoxylin and eosin (H\&E) or Alcian Blue and Periodic Acid Schiff (AB/PAS).

\subsection{Immunohistochemical Detection of $u P A R, K i 67$, and Inflammation Markers in Gastric Mucosa}

Immunohistochemical stainings were performed with the following antibodies: Rabbit polyclonal (pAb) against mouse uPAR [37]; rabbit pAb against H. pylori (Code: B0471), rat anti-mouse Ki67 monoclonal antibody (mAb) (Code: M7249), and pAb against human CD3 (Code: A0452) (Dako, Glostrup, Denmark); and rat anti-mouse F4/80 mAb (Code: Ab6640, Abcam, Cambridge, UK). Sections were pre-treated with Proteinase $\mathrm{K}(10 \mu \mathrm{g} / \mathrm{mL})$ for 10 and $5 \mathrm{~min}$ at $37^{\circ} \mathrm{C}$ for antigen retrieval of uPAR and F4/80, respectively. For H. pylori immunohistochemistry, sections were treated in a T/T Micromed microwave processor (Milestone, Sorisol, Italy) at $98{ }^{\circ} \mathrm{C}$ for $10 \mathrm{~min}$ in target retrieval solution pH 6.0 (Code: 1699, Dako, Glostrup, Denmark). For Ki67 and CD3 staining, tissue sections were treated at $98^{\circ} \mathrm{C}$ for $15 \mathrm{~min}$ in $10 \mathrm{mM}$ sodium citrate $\mathrm{pH} 6.0$ and $10 \mathrm{~min}$ in $10 \mathrm{mM}$ Tris, $0.5 \mathrm{mM}$ EGTA (TEG) at $\mathrm{pH} 9.0$, respectively. In all cases, endogenous peroxidase activity was blocked by incubation in $1 \%$ hydrogen peroxide solution for $15 \mathrm{~min}$. The primary antibodies were diluted in Antibody Diluent (Code: S3022, Dako, Glostrup, Denmark) and incubated at $4{ }^{\circ} \mathrm{C}$ overnight in Shandon racks (Thermo Shandon, Pittsburg, PA, USA) at the following dilutions: Anti-mouse uPAR $1 \mu \mathrm{g} / \mathrm{mL}$, anti-H. pylori 1:700, anti-mouse Ki67 1:200, anti-human CD3 1:2000, and anti-mouse F4/80 1:7000. Subsequently, the primary antibodies against mouse UPAR, H. pylori, and CD3 were detected with EnVision reagent anti-rabbit IgG horseradish peroxidase-conjugated polymers (Code: K4003, Dako, Glostrup, Denmark). The rat anti-mouse Ki67 and F4/80 primary antibodies were detected by incubating the sections for 45 min with rabbit anti-rat immunoglobulins/Biotinylated (Code: E0468, Dako, Glostrup, Denmark), followed by EnVision reagent anti-rabbit IgG horseradish peroxidase-conjugated polymers. Each incubation step was followed by washes in TBS containing $0.5 \%(v / v)$ Triton X-100. Finally, the reactions were visualized by incubating the sections with NovaRED (Vector Laboratories, Burlingame, CA, USA) according to the manufacturer's instructions and counterstained with Mayer's hematoxylin. 
The specificity of uPAR immunoreactivity was verified by the following controls: (1) Pre-incubation of the anti-mouse uPAR pAb with a 10-fold molar excess of purified recombinant soluble mouse uPAR for $2 \mathrm{~h}$ at room temperature; and (2) omission of the pAb against mouse uPAR (i.e., only the secondary antibody was added to the tissue sections).

\subsection{In Vitro Transcription and In Situ Hybridization for uPA}

Antisense and sense uPA probes were generated as described [38]. The ${ }^{35} \mathrm{~S}$-radioactivity of the probes was adjusted by dilution in $10 \mathrm{mM}$ DTT and deionized formamide to $750,000 \mathrm{cpm} / \mu \mathrm{L}$. Then, 3- $\mu \mathrm{m}$ paraffin sections were deparaffinized with xylene, hydrated and washed with $130 \mathrm{mM} \mathrm{NaCl}$, $7 \mathrm{mM} \mathrm{NaH}_{2} \mathrm{PO}_{4}$ (pH 7.0), and pre-treated with TEG-buffer for $10 \mathrm{~min}$ at $98{ }^{\circ} \mathrm{C}$ under RNAse-free conditions, as described [39].

\subsection{Co-Culture Conditions of Human Gastric Cancer Cell Lines and H. pylori Strains In Vitro}

The human gastric adenocarcinoma cell lines AGS (ATCC \#CRL-1739) and MKN45G [40] were cultured in RPMI 1640 GlutaMAX (GIBCO, Life Technologies, Carlsbad, CA, USA) without antibiotics, but supplemented with $6 \%$ heat-inactivated fetal calf serum (GIBCO) at $37{ }^{\circ} \mathrm{C}$ and $5 \% \mathrm{CO}_{2}$. Confluent cultures were trypsinized, and $5 \times 10^{6}$ cells were added to $10-\mathrm{cm}$ tissue culture dishes and allowed to reconstitute overnight, reaching approximately $80 \%$ confluence.

Suspensions of freshly harvested $H$. pylori strains SS1 or J99 were adjusted to an optical density of $600 \mathrm{~nm}=0.25 \mathrm{in}$ RPMI 1640 GlutaMAX without fetal calf serum. Then, $10 \mathrm{~mL}$ of bacterial suspensions (corresponding to $1.0 \times 10^{9} \mathrm{CFU}$ ) or the corresponding buffer controls were added to tissue culture dishes containing adherent MKN45G or AGS cells. After $6 \mathrm{~h}$ of incubation at $37^{\circ} \mathrm{C}$, the co-cultures were washed with PBS and cells were harvested using a cell scraper and collected three times in $300 \mu \mathrm{L}$ 0.1 M Tris $\mathrm{pH}$ 8.1, $10 \mu \mathrm{g} / \mathrm{mL}$ trasylol, and $1 \mathrm{mM}$ phenylmethylsulfonyl fluoride (PMSF). The cell pellets were collected by centrifugation at $12.000 \times g$ for $30 \mathrm{~min}$ at $4{ }^{\circ} \mathrm{C}$ and immediately lysed by re-suspension in $900 \mu \mathrm{L}$ of lysis buffer $(0.1 \mathrm{M}$ Tris $\mathrm{pH} 8.1,0.5 \%(w / v)$ deoxycholat, $1 \%(v / v) \mathrm{NP} 40,0.1 \%(w / v)$ SDS, $10 \mathrm{mM}$ EDTA, $1 \mathrm{mM}$ PMSF, and $10 \mu \mathrm{g} / \mathrm{mL}$ trasylol). Lysis proceeded on ice for $60 \mathrm{~min}$ with short pulses of vortexing every $20 \mathrm{~min}$. Supernatants were isolated by centrifugation at $15.000 \times \mathrm{g}$ for $20 \mathrm{~min}$ at $4{ }^{\circ} \mathrm{C}$.

Detection of uPAR expression in these detergent lysates was assessed by SDS-PAGE of $10 \mu \mathrm{L}$ of lysate $\left(\sim 6 \times 10^{4}\right.$ cells) followed by electroblotting onto PVDF membranes. Excess protein binding sites were blocked by incubation with $2 \%(w / v)$ skim milk powder. Visualization of uPAR expression was subsequently accomplished by first an overnight incubation at $4{ }^{\circ} \mathrm{C}$ with $0.1 \mu \mathrm{g} / \mathrm{mL}$ of the primary rabbit anti-uPAR pAb and a second 1-h incubation at room temperature with a 5000-fold dilution of secondary HRP-conjugated swine anti rabbit-Ig pAb (Code P 0217, DAKO, Glostrup, Denmark). Specificity was validated by pre-incubation of the primary rabbit anti-uPAR antibody with a 10-fold molar excess of purified soluble uPAR expressed in Drosophila S2 cells [41], before addition to the PVDF membrane. Equal loading conditions were assessed after stripping the membrane and reprobing the blots with a mouse anti $\beta$-actin mAb (code: mAbcam 8226; Abcam, Cambridge, UK).

\subsection{H. pylori Colonization, Histopathology and Immunohistochemistry Evaluations}

The H. pylori colonization was evaluated according to the number of gastric glands containing bacteria and the density of bacteria, as proposed [42]. Histopathological evaluations of the mouse gastric mucosa and uPAR expression were scored by two independent observers and graded using published guidelines [43], focusing particularly on inflammation and metaplasia. Scoring was done in a blinded manner by the two observers and a consensus was subsequently reached before the identity of the samples were decoded. Infiltration of inflammatory cells in the gastric mucosa was determined by counting the absolute number of CD3-positive and F4/80-positive cells per microscopic visual field (approximately $0.2 \mathrm{~mm}^{2}$ ) using the ImageJ software (available at: https://imagej.nih.gov/ij/). A cell proliferation index was estimated as the proportion of Ki67-positively stained nuclei per gastric gland in at least 5 well-oriented glands. Semi-quantitative assessment of uPAR expression was based on the 
intensity of staining in gastric epithelial cells according to the following categories: 0 , negative; 1 , weak; 2, moderate; 3, intense; and 4, very intense. Scorings for all parameters was performed independently at five anatomical locations of the mouse stomach: The squamo-columnar junction, two sites of the corpus (proximal and distal segments), the region encompassing the transitional mucosa between the corpus and antrum (denoted mid-stomach), and the antrum. Since statistical analysis revealed very similar results for the two anatomical sites of the corpus, we refer to the corpus as a single entity and all our statistical analyses correspond to data collected for the proximal corpus only.

\subsection{Statistical Analysis}

The association between variables on an ordinal scale is presented by the Spearman rank correlation. The general linear model was used for the analysis of continuous variables (CD3, F4/80, and Ki67) with time PI, antimicrobial treatment, or $\mathrm{PGE}_{2}$ treatment as explanatory variables. For categorical variables on an ordinal scale (inflammation and uPAR scores), chi-square tests for trend were used to compare pre-specified pairwise comparisons with exact $p$-values. The analysis of categorical variables on an ordinal scale and time of measurement were done using a proportional odds regression analysis. $p$-values less than 5\% were considered significant. All calculations were done using SAS (v. 9.2, SAS Institute, Cary, NC, USA).

\section{Results}

\subsection{Histopathological Changes Induced by H. pylori Infection}

H. pylori infection causes a number of well-described histopathological changes in the gastric epithelium of colonized mice [43]. We analyzed the occurrence of these lesions in cohorts of H. pyloriinfected mice from 3 to 30 weeks PI. First, we interrogated the H. pylori colonization status of the animals by immunohistochemistry and found bacteria in the luminal space along the gastric epithelium at all time-points. Bacterial clusters of variable density were generally observed in close proximity to or in direct contact with epithelial cells in the upper third of the mucosa, in particular at the proximal segment of the corpus (Supplementary Figure S1). Three weeks after colonization, $H$. pylori-infected mice had normal gastric mucosal architecture with very few scattered inflammatory cells within the lamina propia, comparable to non-infected animals (Supplementary Figure S2). Six weeks after challenge, a minor influx of inflammatory cells was observed focally at the base of the gastric glands (Figure 2C,D), while in general, the mucosal architecture resembled that of unchallenged mice (Figure 2B). Distinct histopathological lesions were first observed in H. pylori-infected mice after 10 weeks of colonization, particularly in the corpus. At this time-point, overt multifocal infiltration of inflammatory cells in the mucosa and submucosa was observed (Figure 2A). CD3-positive cells (T-cells) were identified as the main inflammatory cell type recruited to these compartments of the gastric wall (Figure 2A). Other infiltrating immune cells were also seen, including F4/80-expressing cells (primarily macrophages) and neutrophils (Figure 2A). In addition, these mice exhibited functional loss of parietal cells, which were replaced by mucous-secreting cells, accompanied by alterations in the production of gastric mucins (Figure 2A), all being morphological hallmarks of a developing mucous metaplasia. Inflammation and mucous metaplasia were further exacerbated at 25 weeks PI (Figure 2B-D). Thirty-week-infected mice displayed robust infiltration of inflammatory cells and manifest mucous metaplastic lesions encompassing large areas of the corpus and mid-stomach (Figure 2A). Foci of pseudopyloric metaplasia were observed in the most proximal part of the corpus (not shown). In contrast, no overt histopathological alterations were observed in the antral region of the mouse stomach at any time-point (not shown). Histopathological assessment revealed an overall continuous progression of the inflammation during the course of infection (Figure 2B, $p=0.002$ ). Concordantly, the number of infiltrating CD3-positive and F4/80-positive cells in the corpus correlated to the duration of infection (Figure $2 \mathrm{C}, \mathrm{D}, p<0.0001 ; \mathrm{r}_{\mathrm{S}}=0.72$, and $p<0.0001$; $r_{\mathrm{S}}=0.70$, respectively). A similar correlation was established for the mid-stomach $\left(p<0.0001 ; r_{\mathrm{S}}=0.60\right.$ for CD3 and $p=0.0002 ; \mathrm{r}_{\mathrm{S}}=0.55$ for F4/80). 


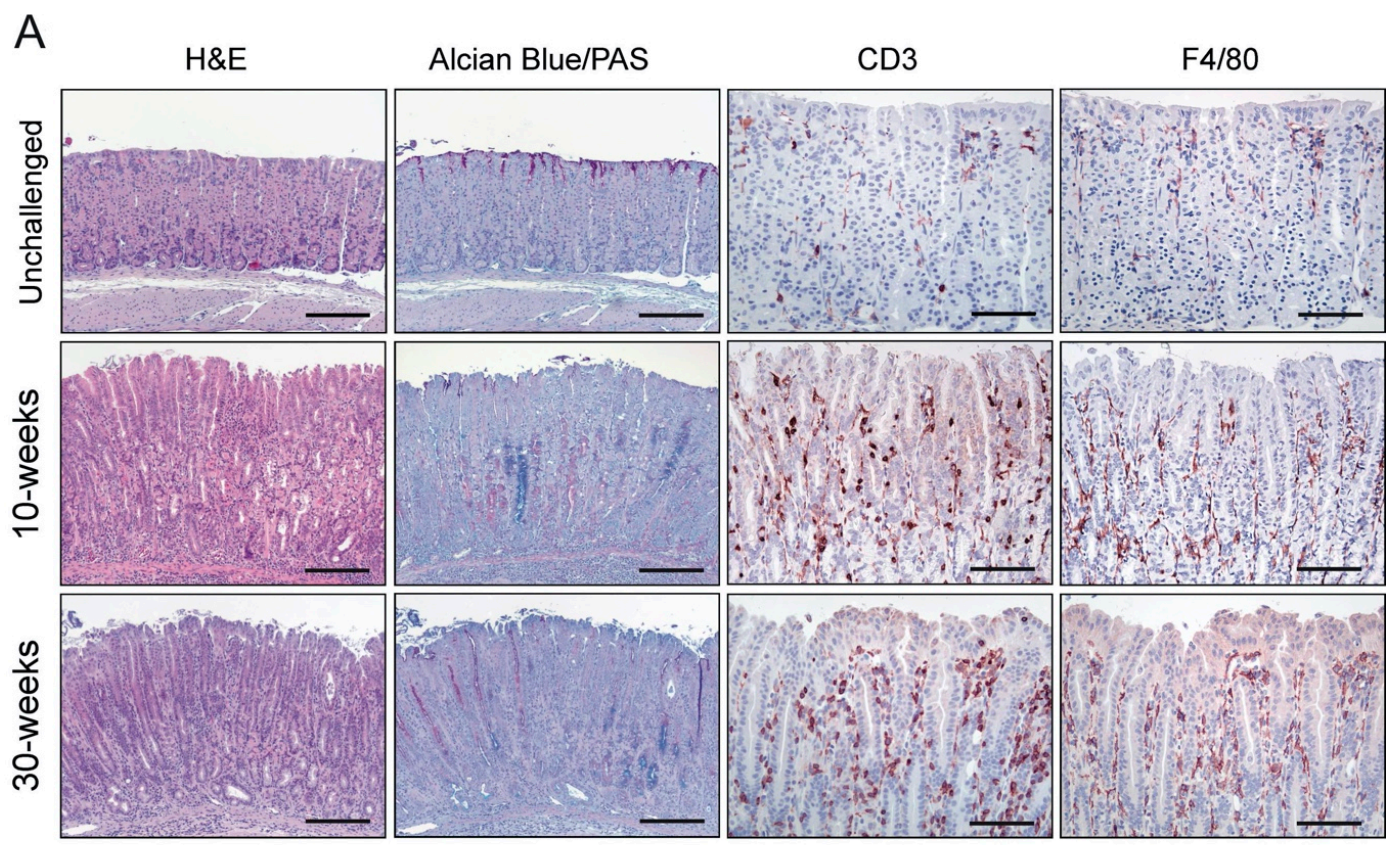

B

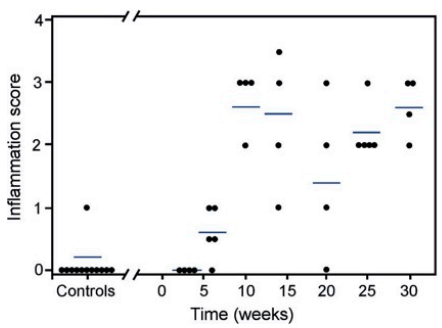

$\mathrm{C}$

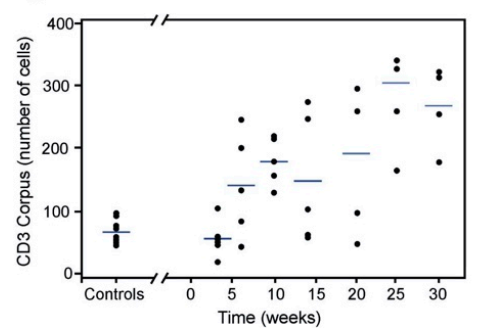

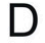

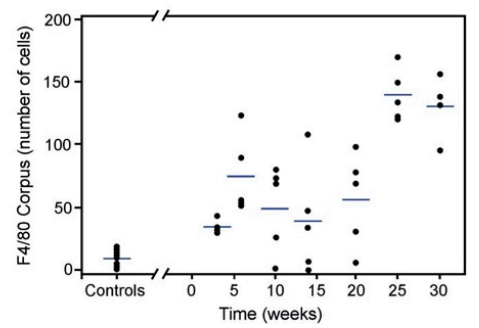

Figure 2. Histopathology of the murine gastric corpus mucosa with chronic H. pylori infection. Adjacent tissue sections from resected gastric mucosa of unchallenged and $H$. pylori-inoculated mice were stained by H\&E and Alcian Blue/PAS or processed for immunohistochemical detection of CD3 and F4/80 (A). Unchallenged mice (upper row) show a normal mucosal architecture. Ten weeks after H. pylori inoculation (middle row), pronounced histological alterations are observed in the corpus, including inflammation (CD3 and F4/80) and mucous metaplasia with shifts towards intestinal-type acidic mucins (blue) and gastric-type neutral mucins (pink) in the oxyntic mucosa (Alcian Blue/PAS staining). This pathology is further exacerbated on sustained infection at 30 weeks (lower row). Histopathological assessment of inflammation (scored according to the scheme proposed by [43]) (B), infiltrating CD3-positive (C) and F4/80-positive cells (D) in the mucosa of non-infected (controls, $n=9$ ) and $H$. pylori-challenged mice at different time-points (one experiment; $n=4-5$ mice per timepoint) with the blue line representing mean values. Scale bars in A: H\&E and Alcian Blue/PAS microphotographs $\approx 200 \mu \mathrm{m}, \mathrm{CD} 3$ and F4/80 microphotographs $\approx 100 \mu \mathrm{m}$.

\subsection{H. pylori Infection Induces uPAR Expression in Gastric Epithelial Cells}

We have previously shown that uPAR expression is upregulated in foveolar epithelial cells of human gastric mucosa colonized with H. pylori [29]. To further explore this finding, we tested whether it is recapitulated in experimental mouse models of $H$. pylori-induced gastritis. In unchallenged animals, uPAR is only confined to endothelial cells and a few scattered neutrophils within the lamina propia of the mucosa and submucosal layer of the stomach wall (Figure 3A). These two cell types constitutively express uPAR under normal homeostatic conditions [10]. Intriguingly, we always observed a pronounced and persistent uPAR staining in a small cluster of epithelial cells delimiting the junction between squamous and columnar stomach in unchallenged mice (Figure 3B), but no uPAR expression occurred in the epithelial compartment of the corpus and mid-stomach in non-infected animals (Figure 3A). Epithelial cells located in the antral 
region were nevertheless positive for UPAR in unchallenged animals (Figure 3C). In mice infected with H. pylori for 30 weeks, uPAR expression persisted in endothelial cells and infiltrating neutrophils, whereas uPAR expression in transitional cells residing in the squamo-columnar junction surprisingly disappeared (not shown). More importantly, intense de novo uPAR immunoreactivity appeared in the columnar epithelium of the corpus and mid-stomach in H. pylori-colonized mice (Figure 3D). This uPAR expression was confined to the apical surface of foveolar epithelial cells located in the upper third of the gastric units (pits) (Figure 3D,E). Other cell types of the epithelial layer, such as mucous neck, parietal, and chief cells, located in the neck and base of the gastric glands remained UPAR negative (Figure 3D). In contrast, the baseline expression of UPAR in epithelial cells of the antrum remained insensitive to the $H$. pylori infection (Figure 3F).
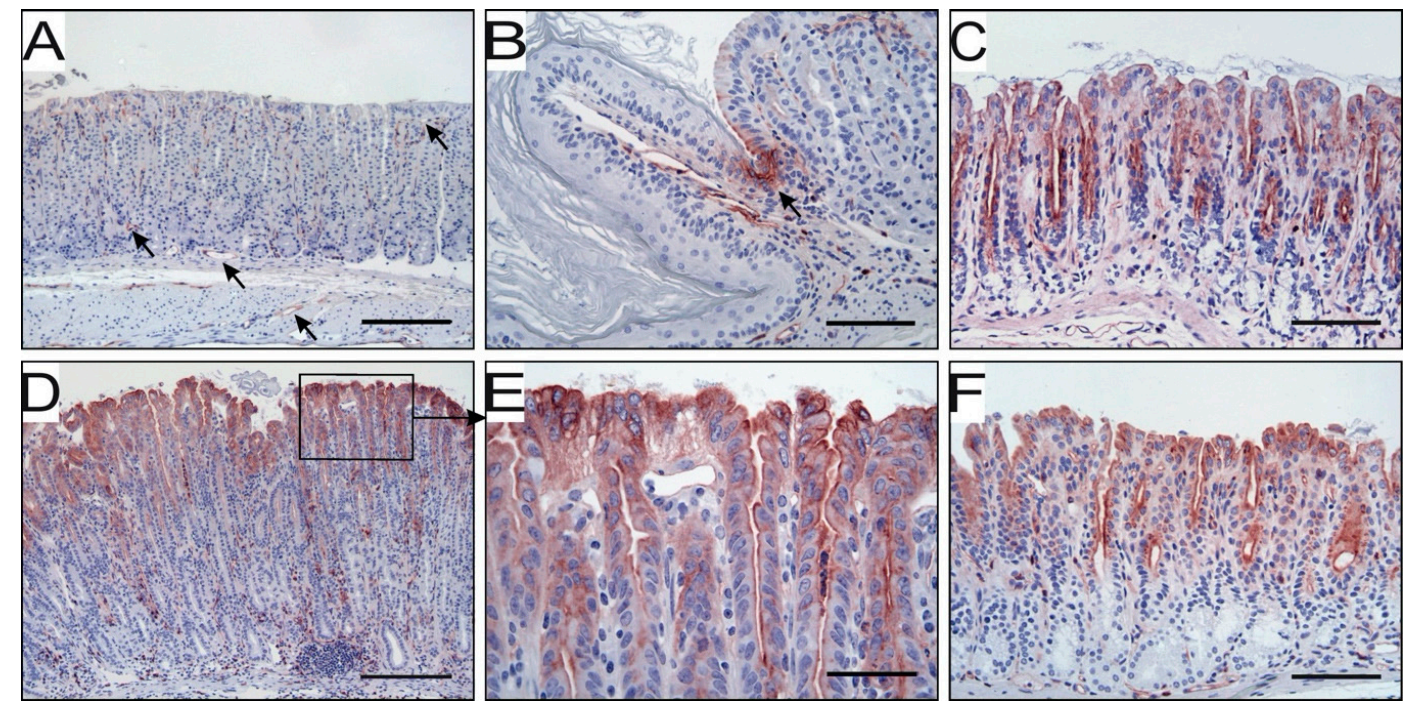

Figure 3. uPAR expression at different anatomical locations in non-infected and H. pylori-challenged mice. In the corpus of unchallenged mice, uPAR is detected by immunohistochemistry in endothelial cells (arrows) and a few scattered neutrophils (A), as well as in some transitional cells of the squamo-columnar junction (B). Epithelial cells in the corpus are negative for uPAR (A), while some expression is found in antral epithelium (C). Thirty weeks after H. pylori inoculation, intense uPAR expression appears in the corpus epithelium (D) at the apical membrane of foveolar epithelial cells (E). Epithelial cells of the antrum remain uPAR positive in $H$. pylori-infected mice $(\mathbf{F})$. Scale bars: A and D $\approx 200 \mu \mathrm{m} ; \mathrm{B}, \mathrm{C}$ and $\mathrm{f} \approx 100 \mu \mathrm{m} ; \mathrm{E} \approx 50 \mu \mathrm{m}$.

More distal regions of the gastrointestinal tract were also examined in our mouse model. In both uninfected and $H$. pylori-challenged animals, uPAR was present in endothelial and infiltrating inflammatory cells, presumably neutrophils, within the lamina propia of the crypts, but never in the epithelial compartment of the small intestine and colon (Supplementary Figure S3A-C).

The specificity of our immunohistochemical detection of mouse uPAR was validated by pre-absorption controls (Supplementary Figure S3D-I).

\subsection{UPAR Expression Levels, Inflammation, and Cell Proliferation Increase with the Duration of H. pylori Infection}

The kinetics of uPAR induction by H. pylori was delineated by a semi-quantitative scoring of uPAR immunostaining at different anatomical locations of the mouse stomach. This revealed a progressive overall increase in the intensity of UPAR staining in foveolar epithelial cells of the corpus as a function of the duration of infection (Figure $4 \mathrm{~A}, \mathrm{~B}, p=0.006 ; \mathrm{r}_{\mathrm{S}}=0.57$ ). In the antral region, in contrast, the correlation between these two parameters was weak but negative (Supplementary Figure S4B, $p=0.03$; $\left.r_{S}=-0.22\right)$. At the squamo-columnar junction, an unexpected negative correlation existed between $\mathrm{UPAR}$ expression and the time post-infection (Supplementary Figure S4A, $p<0.0001 ; \mathrm{r}_{\mathrm{S}}=-0.70$ ). 
Given the paired increment of both inflammation and UPAR expression, the potential link between these two parameters was further scrutinized. A strong correlation between the number of infiltrating CD3-positive cells and the intensity of UPAR expression in epithelial cells was revealed for the corpus and mid-stomach ( $p<0.0001, \mathrm{r}_{\mathrm{S}}=0.65$ for corpus; Figure $2 \mathrm{C}$ vs. Figure 4B). Similarly, the number of infiltrating F4/80-positive cells and UPAR expression in epithelial cells at these anatomical sites were highly correlated ( $p<0.0001, \mathrm{r}_{\mathrm{S}}=0.74$ for corpus; Figure $2 \mathrm{D}$ vs. Figure $4 \mathrm{~B}$ ).
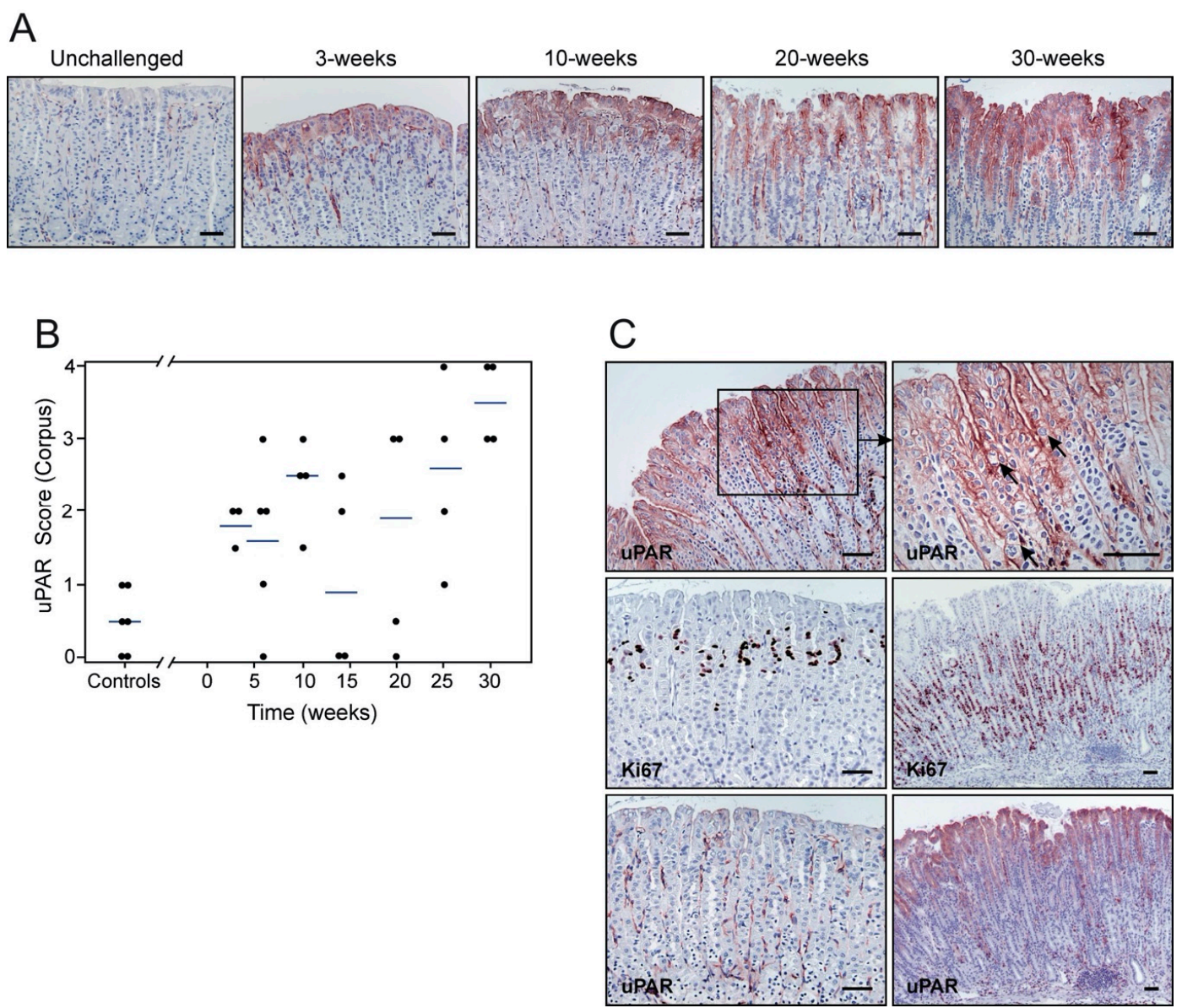

Figure 4. Kinetics of H. pylori-induced uPAR expression and cell proliferation in the gastric epithelium. Sections from unchallenged, 3-, 10-, 20-, and 30-week post-inoculation (PI) mice were examined by immunohistochemistry for uPAR (A,C) and Ki67 (C) expression. Semi-quantitative assessments reveal a progressive increase in uPAR intensity $\left(\mathbf{B} ; p=0.006 ; \mathrm{r}_{\mathrm{S}}=0.57\right)$ (one experiment; $n=9$ controls; $n=4-5$ H. pylori-challenged mice per timepoint), which is correlated with cell proliferation $\left(p<0.0001 ; \mathrm{r}_{\mathrm{S}}=0.70\right)$. Corresponding uPAR and Ki67 staining on adjacent sections from non-infected (left) and infected (right) mice are shown $(\mathbf{C})$. Arrows indicate the presence of mitotic figures. Scale bars $\approx 100 \mu \mathrm{m}$.

The UPAR staining in foveolar epithelial cells of $H$. pylori-colonized mice was particularly intense in areas of the gastric mucosa where mitotic figures were abundant (Figure 4C). Accordingly, we estimated a cell proliferation index, based on Ki67 staining, and explored if a correlation between uPAR expression and epithelial cell proliferation existed. Cell proliferative activity in the corpus and mid-stomach was substantially enhanced in H. pylori-colonized mice, compared to unchallenged mice (Figure 4C), and increased according to time PI ( $p=0.0003 ; \mathrm{r}_{\mathrm{S}}=0.54$ for corpus). Notably, a strong correlation existed between cell proliferation and UPAR expression in the corpus mucosa $\left(p<0.0001 ; \mathrm{r}_{\mathrm{S}}=0.70\right)$, and in the mid-stomach $\left(p=0.0002 ; r_{s}=0.62\right)$. It should, nonetheless, be emphasized that uPAR expression and cell proliferation take place at almost non-overlapping anatomical locations of the epithelial lining (Figure 4C). 


\section{4. uPA is Not UpRegulated in Gastric Mucosa Upon H. pylori Infection}

The observed induction of UPAR in the mouse gastric epithelium in response to H. pylori infection prompted us to investigate whether a parallel induction of its cognate binding partner, uPA, was evident. In situ hybridization demonstrated uPA mRNA signal in all anatomical locations of the mouse stomach in both non-infected and H. pylori-infected mice after 6, 10 and 14 weeks of PI (Supplementary Figure S5A,D,G and Supplementary Figure S5B,E,H, respectively). Negative controls using the corresponding sense probes showed no uPA signal (Supplementary Figure S5C,F,I). In general, uPA-positive cells were located within the lamina propia of the mucosa, especially at the luminal edge of the gastric units, whereas epithelial cells were devoid of uPA mRNA signal (Supplementary Figure S5D-E, Supplementary Figure S5G-H).

\subsection{Antimicrobial Eradication of H. pylori Infection Downregulates uPAR Expression}

To clarify the mechanism responsible for induction of uPAR expression in response to $H$. pylori infection, we investigated whether a sustained colonization was required to drive the expression of UPAR in the gastric epithelium. In this line of experiments, mice were inoculated with H. pylori (one single dose) and a manifest infection was allowed to establish for 14 weeks before initiating the antimicrobial therapy against $H$. pylori. Animals were sacrificed 1,3 , and 5 weeks after treatment and compared to $H$. pylori-colonized sham-treated animals and uninfected mice. H. pylori bacteria were observed lining the gastric epithelium of all inoculated and sham-treated animals in the experimental cohort, except for those receiving the antibiotic treatment (not shown). Histological evaluation of infected and sham-treated animals showed significant inflammation of the stomach (Figure 5A,B and Supplementary Figure S6), increased cell proliferation (Figure 5A,C), and developing mucous metaplasia (Supplementary Figure S6). These histopathological aberrations of the gastric mucosa persisted one week after termination of the anti-H. pylori therapy, and normal mucosal architecture was gradually restored, reaching full restoration after 5 weeks (Figure 5A-C and Supplementary Figure S6).

Concordant with our above-described experiments, intense uPAR expression was induced in foveolar epithelial cells of the corpus and mid-stomach in H. pylori-colonized and sham-treated mice (Figure 5A,D). Importantly, uPAR staining in foveolar epithelial cells at these two anatomical regions was indeed very weak, if present at all, in mice undergoing antimicrobial therapy for $H$. pylori eradication (Figure 5A,D). The expression of UPAR in the antral epithelium remained at the baseline level in inoculated mice irrespective of the treatment (not shown). These results demonstrate that persistent $H$. pylori colonization of the mouse gastric epithelium is required for sustained induction of UPAR expression in foveolar epithelial cells of the corpus and mid-stomach. Intriguingly, uPAR expression in transitional cells residing in the squamo-columnar junction reappeared in parallel with successful H. pylori eradication (not shown).

3.6. Treatment with PGE 2 Attenuates Gastric Immunopathology but Does Not Abrogate uPAR Expression in H. pylori-infected Mice

Treatment of $H$. felis-infected mice with synthetic $\mathrm{PGE}_{2}$ analogs strongly attenuates inflammation without perturbing the chronic bacterial colonization [36]. We then reasoned we could use $\mathrm{PGE}_{2}$ synthetic analogs in our mouse model as a means to uncouple the intrinsic connection between H. pylori infection and inflammation. More specifically, we considered this approach well-suited to interrogate whether the observed induction of UPAR is caused by the direct interaction of $H$. pylori with the gastric epithelial cells, or is a bystander phenomenon elicited by the inflammatory response mounted against the infection. 
A
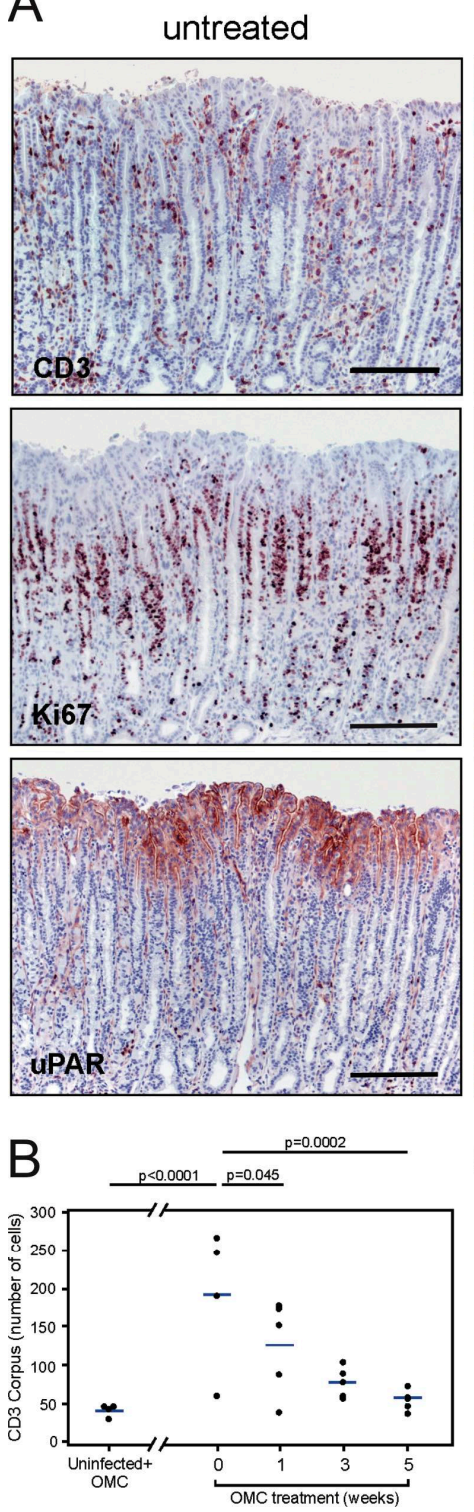

1-week OMC
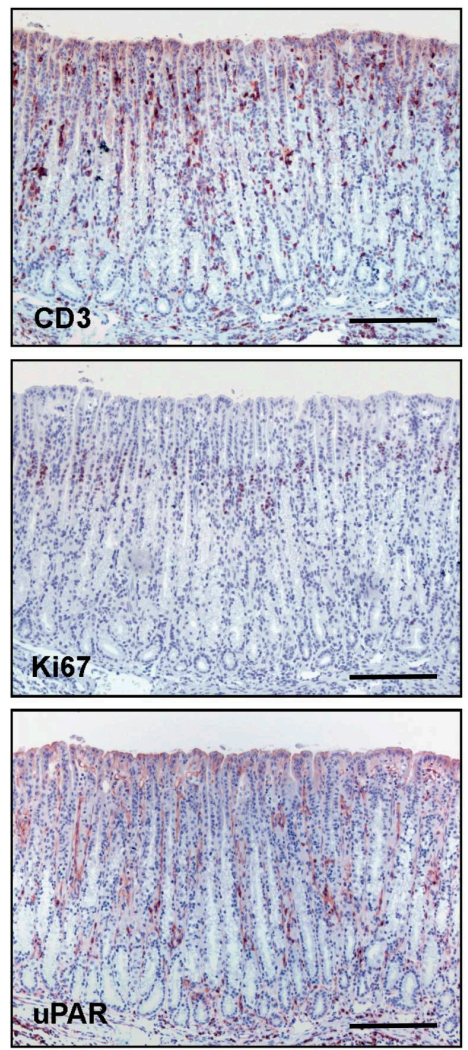

C

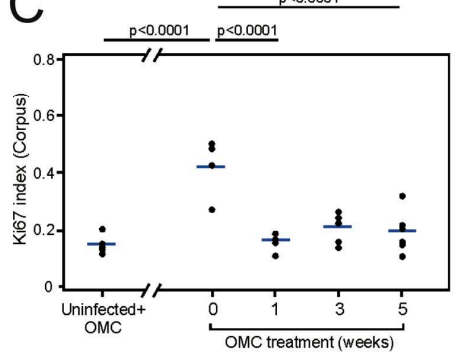

5-weeks OMC
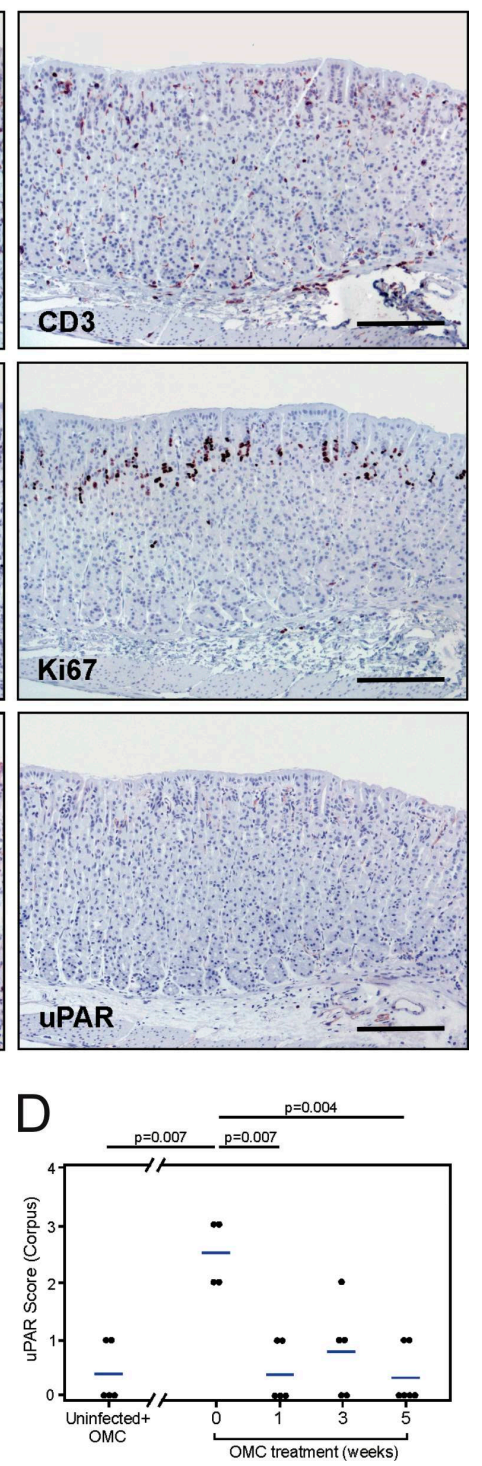

Figure 5. Effect of antimicrobial therapy on uPAR expression in the mouse gastric epithelium. Adjacent sections from 14-week $H$. pylori-infected mice untreated (A, left column) or treated with antibiotics (A, middle and right column) were processed for CD3, Ki67, and UPAR expression. Semi-quantitative assessments of infiltrating CD3-positive cells (B), cell proliferation activity (C), and uPAR staining intensity (D) in the corpus of the mouse stomach for each of the studied groups. One experiment with $n=4-5$ mice per experimental group. Scale bars: CD3, Ki67, and uPAR microphotographs in $\mathrm{A} \approx 200 \mu \mathrm{m}$. OMC; omeprazole, metronidazole, clarithromycin.

In agreement with the findings reported in [36], we found increased H. pylori colonization in the stomachs of $\mathrm{PGE}_{2}$-treated mice compared to sham-treated animals (semi-quantitative average score for bacterial colonization: 2.4 for $\mathrm{PGE}_{2}$-treated and 1.4 for untreated mice). Untreated H. pylori-infected mice exhibited the usual histopathology 14 weeks after challenge, including robust infiltration of inflammatory cells in the mucosa and submucosa, mucous metaplastic lesions, and enhanced epithelial cell proliferation in the corpus and mid-stomach (Figure 6A-C and Supplementary Figure S7). These animals also showed a pronounced UPAR staining in the foveolar epithelial cells of the corpus (Figure 6A,D). In contrast, $H$. pylori-infected mice undergoing $\mathrm{PGE}_{2}$ treatment showed almost normal mucosal architecture, substantial downregulation of the inflammatory response, unaltered mucin 
production, and a cell proliferation activity comparable to that of non-infected animals (Figure 6A-C and Supplementary Figure S7).

A

14-weeks + PBS
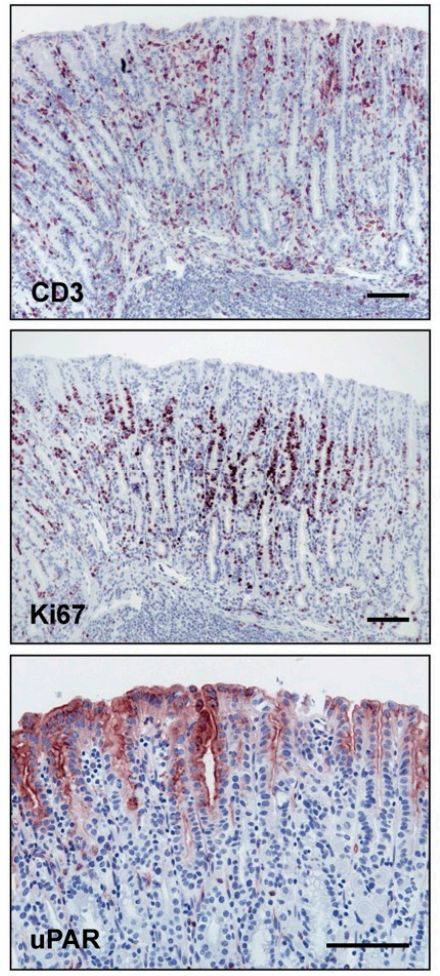

14-weeks $+\mathrm{PGE}_{2}$
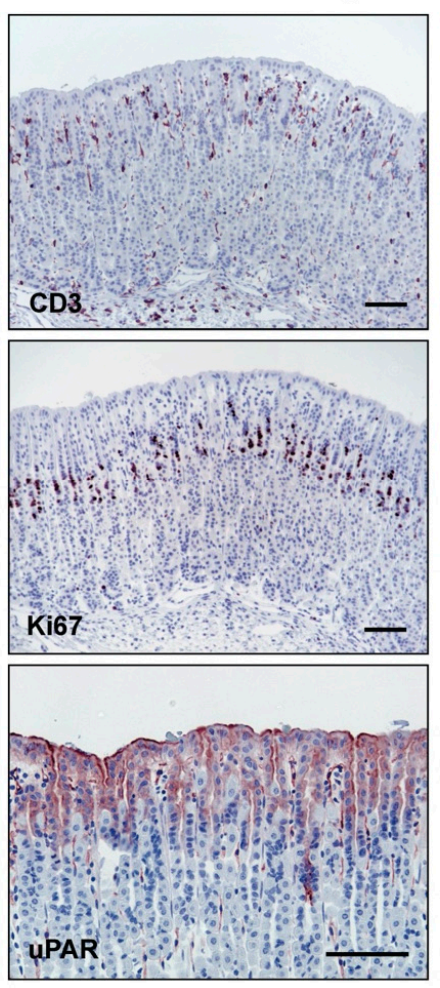

B
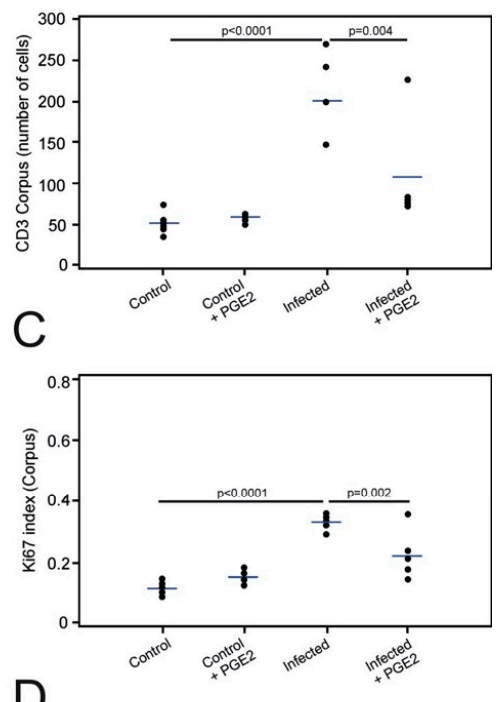

$\mathrm{D}$

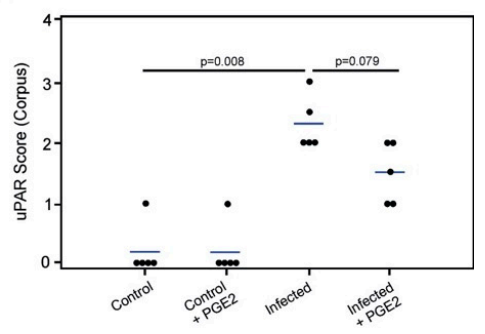

Figure 6. Effect of $\mathrm{PGE}_{2}$ treatment on uPAR expression in gastric epithelium colonized with H. pylori. Adjacent sections from the gastric mucosa of 14-week H. pylori-inoculated mice treated with saline (PBS) (A, left column) or with $\mathrm{PGE}_{2}$ analogs (A, right column) were processed for immunohistochemistry (CD3, Ki67, and uPAR). Semi-quantitative assessment of infiltrating CD3-positive cells (B), cell proliferation activity (C), and uPAR staining intensity (D) in the corpus region of the mouse stomach for each of the studied groups. One experiment with $n=4-5$ mice per experimental group. Scale bars $100 \mu \mathrm{m}$.

This remission was accompanied by a reduction in the expression of UPAR in epithelial cells of the corpus mucosa after treatment with $\mathrm{PGE}_{2}$ analogs, although it did not reach statistical significance (Figure 6A,D; $p=0.079$ ). Although these data suggest that $H$. pylori-driven inflammation does contribute to the induction of uPAR expression in mouse gastric epithelium, a remnant uPAR protein expression did persist after treatment, which may indicate that the direct interaction of $H$. pylori with the epithelial lining could represent an additional contributing factor to the induction of uPAR protein expression.

\subsection{H. pylori Induces uPAR Expression in Co-Cultured Gastric Adenocarcinoma Cell Lines}

Several in vitro studies indicate that $H$. pylori induces uPAR expression in gastric adenocarcinoma cell lines [44,45]. In conjunction with the fact that $\mathrm{PGE}_{2}$ analogs do not eliminate uPAR expression in vivo, this prompted us to interrogate the induction of UPAR protein in vitro by exposure to the mouse-adapted SS1 strain of H. pylori. We co-cultured a variety of H. pylori strains, including SS1, with the gastric adenocarcinoma cell-lines AGS and MNK45G and analyzed the uPAR content in the corresponding total cell lysates. This minimalistic setup shows that, at least in vitro, $H$ pylori strain SS1 did indeed induce uPAR expression in both cell lines after only $6 \mathrm{~h}$ of co-cultivation (Figure 7). In line with previous studies [46], H. pylori strain J99 also induced uPAR expression in our in vitro setup. 

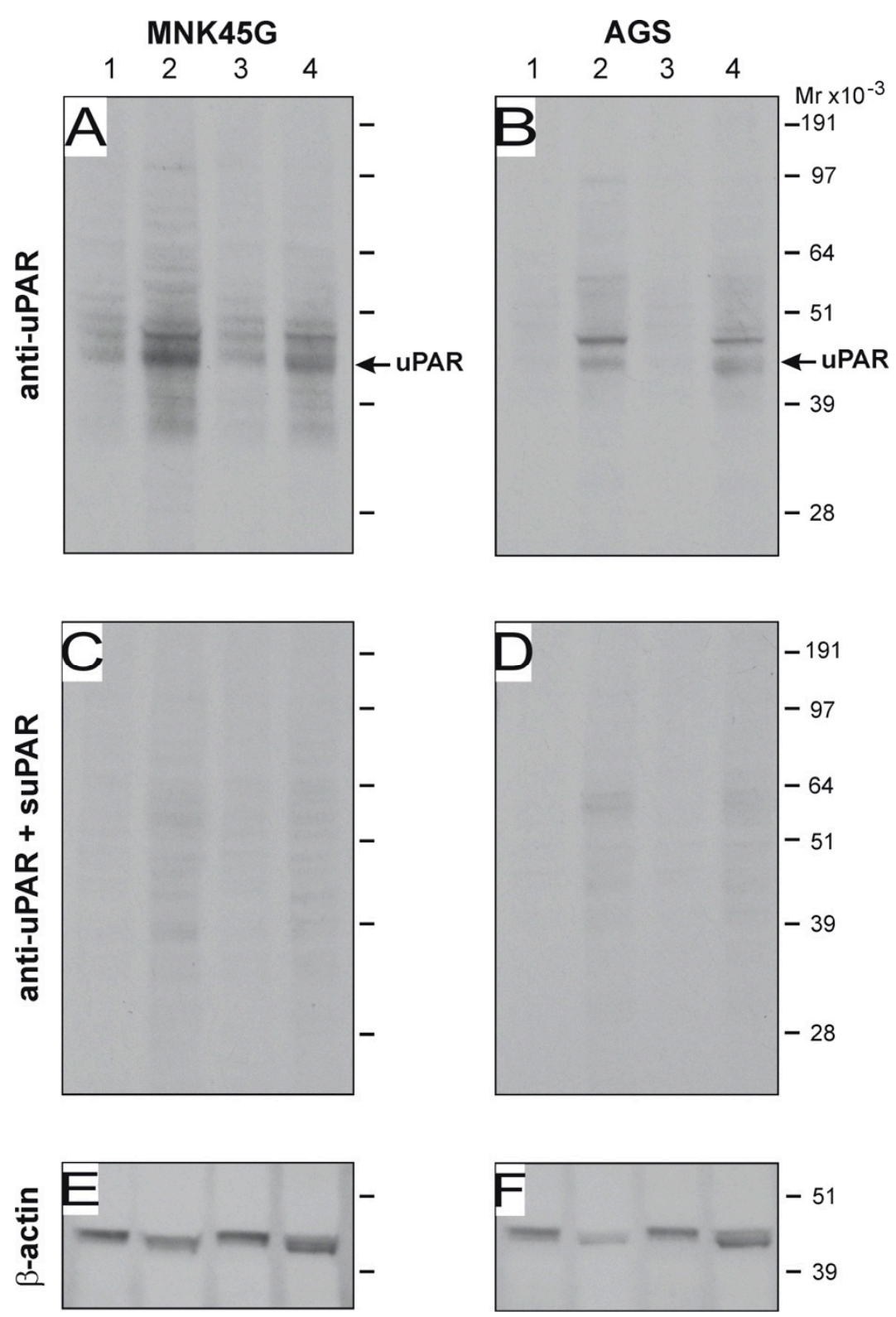

Figure 7. H. pylori-induced uPAR expression in gastric cancer cell lines in vitro. The gastric carcinoma cell-lines MNK45G and AGS (5 $\times 10^{6}$ cells) were co-cultured with $1 \times 10^{9} \mathrm{CFU}$ of $H$. pylori strains SS1 and J99 in serum-free RPMI media for $6 \mathrm{~h}$ at $37^{\circ} \mathrm{C}$. Western blotting of cells lysates and corresponding sham controls were developed with an anti-uPAR pAb (A,B), and the specificity of this detection is verified by pre-absorption with purified uPAR (C,D). After stripping, the equal loading was probed by staining for $\beta$-actin (E,F). Sham-treated control cells (lanes 1 and 3); cells co-cultured with SS1 (lane 2); cells co-cultured with J99 (lane 4). Su-PAR; soluble uPAR. Experiment performed in triplicate.

\section{Discussion}

H. pylori infection is the most well-established risk factor for several gastric pathologies, such as gastritis, peptic ulcer disease, MALT lymphoma, and gastric cancer [3]. Nevertheless, many aspects of the pathogenesis of this bacterial infection still remain enigmatic. Only a small proportion of $H$. pylori-infected individuals develop the above-mentioned pathologies. This feature defines one of the most intriguing paradoxes about this bacterial infection. Presumably, the interaction between $H$. pylori virulence factors, the host response, and the environment dictates the final clinical outcome. Circumstantial evidence suggests that this bacterial infection may be involved in the induction of components of the plasminogen 
activation system in the gastric mucosa, in particular uPAR [27,29]. This phenomenon may be relevant for the development of gastric pathologies, given the central role of UPAR in plasminogen-mediated extracellular matrix remodeling [47-49], vitronectin-dependent cell adhesion and migration [14,15], and its upregulation in gastric cancer and associated prognostic impact $[11,29,49]$.

In the present study, we used a mouse model of H. pylori-induced gastritis to explore the relationship between $H$. pylori infection and uPAR expression in vivo, including a spatio-temporal resolution of UPAR induction during $H$. pylori colonization as well as during its eradication by pharmacological intervention. We now demonstrate that $H$. pylori infection plays an important role in the induction of UPAR protein expression in foveolar epithelial cells of the mouse gastric mucosa, which is mainly a reaction of the inflammatory response triggered by the infection. The anatomical location of this aligns excellently with previous findings in human non-neoplastic gastric mucosa showing that uPAR is highly expressed by surface epithelial cells of $H$. pylori-infected patients, as interrogated locally by immunohistochemistry [29], or globally by measuring uPAR mRNA levels [27]. By studying the kinetics of $H$. pylori-driven uPAR induction, we now reveal four new properties: i) The induction of UPAR expression is confined to the foveolar compartment in the gastric epithelium; ii) it represents an early event in the pathogenesis of the infection; iii) it requires sustained bacterial colonization; and iv) it is associated with the inflammatory-mediated reaction.

We also addressed in our mouse model of H. pylori-induced gastritis whether the uPAR's ligand, uPA, was upregulated in the gastric mucosa, given that some in vitro and in vivo studies claim that uPA is also induced by H. pylori $[27,44]$. We found a baseline expression of uPA mRNA by in situ hybridization in cells located within the lamina propia, which remained insensitive to presence of $H$. pylori, the degree of inflammation, and the duration of infection; no uPA expression was seen in the gastric epithelial cells whatsoever. Thus, it is likely that the induction of UPAR in the gastric epithelium in response to $H$. pylori infection does not lead to activation of plasminogen since the uPA-expressing cells are located in a separate compartment of the gastric mucosa.

One of the strategies $H$. pylori uses to secure survival is to colonize less acidic regions of the stomach [50,51]. In humans and mice, H. pylori is usually found in the mucous layer lining the gastric epithelium and/or anchored to the apical membrane of foveolar cells in the upper third of the mucosa [51-53]. In the present study, the foci in the epithelial compartment where uPAR is upregulated coincide with such preferred niches of $H$. pylori colonization, thus recapitulating the situation found in humans [29]. Nonetheless, the anatomical regions of the stomach preferred for the early phases of $H$. pylori establishment differ between humans and mice. While colonization usually starts in the human antrum [1], H. pylori primarily settle in the most proximal part of the murine columnar stomach, close to the squamo-columnar junction, and expand progressively through the corpus [43]. This route of colonization perfectly mirrors that for the induction of de novo uPAR protein expression, which may imply a causative correlation between the two.

uPAR expression is increased in chronic inflammatory conditions, including wound healing, rheumatoid arthritis, Crohn's disease, chronic ulcerative colitis, and chronic hepatic inflammation [37,47,54-56]. In fact, the severity of collagen-induced arthritis in mice is causally linked to UPAR expression as the severe phenotype in these mice is mitigated upon genetic ablation of UPAR, or pharmacological intervention with monoclonal antibodies [57,58]. In most solid cancers, UPAR is focally upregulated at the invasive front of the malignant tumor, which is generally characterized by a robust infiltration of inflammatory cells that are UPAR positive [13]. In the early non-malignant reactive changes of the gastric epithelium, it is the foveolar epithelial cells, and not infiltrating inflammatory cells, that express uPAR. The correlation between UPAR expression and inflammation may nevertheless indicate the presence of either a single driving biochemical stimulator or two separate events sharing almost overlapping kinetics. Our findings in the H. pylori-colonized mice systemically treated with synthetic PGE 2 analogs tend to favor the former scenario, even though uPAR expression is not fully abrogated. Therefore, we cannot rule out the possibility that to a lesser extent H. pylori per se induces uPAR expression in epithelial cells. The latter is supported by two independent observations: i) UPAR expression appeared already three weeks PI, before any manifest 
inflammatory response mounted against H. pylori could be detected; and ii) H pylori strains do induce uPAR expression in cell lines (further discussed below).

Importantly, we find that eradication of the manifest $H$. pylori infection suppresses uPAR expression even before normal gastric epithelial architecture is restored, demonstrating that sustained colonization is required for the maintenance of elevated UPAR levels in foveolar epithelial cells. In mouse models of Helicobacter-induced gastritis, eradication of the bacterial infection with antimicrobial therapy is completed within $24 \mathrm{~h}$ [35], and this leads to a subsequent restoration of the normal mucosal architecture [59]. In our model, downregulation of UPAR expression is accomplished already after one week, whereas regression of inflammation and mucous metaplasia gradually occurs after termination of the antimicrobial treatment. The turnover time of foveolar epithelial cells is as short as 3 to 4 days [60], which enables us to resolve and separate the direct impact of $H$. pylori infection/eradication on uPAR induction from the slower development of general gastric pathology.

Although the induction of UPAR in gastric epithelial cells to a large extent is driven by the inflammatory reaction elicited in response to $H$. pylori, several in vitro studies show that in co-cultures, the bacterium induce uPAR expression in gastric adenocarcinoma cell lines [44,45]. Accordingly, global gene expression analyses rank uPAR among the top upregulated genes in response to this infection [23,24]. A few studies report that the induction of UPAR in gastric cancer cell lines is predominantly linked to CagA-positive strains [23,44]. Nonetheless, we provide both in vivo and in vitro evidence showing that UPAR also can be induced by $H$. pylori SS1 strain, which is regarded as cagA positive but has lost the functionality of the cag PAI upon its adaptation to mouse gastric physiology [61-63].

We show here in vivo that one of the consequences of $H$. pylori infection is the induction of uPAR protein expression in gastric epithelial cells very early in the course of infection. Importantly, our experimental evidence highlights the persistence of $H$. pylori bacteria in the proximity of the epithelial lining as a necessary event for the induction of UPAR, which adds a new parameter to the pathogenicity of this bacterial infection. Although some in vitro studies have elaborated further on the mechanisms underlying the induction of UPAR in response to H. pylori infection $[45,46]$, additional mechanistic studies in vivo are warranted. Additionally, the functional implications of this phenomenon in the development of gastric pathologies remain to be clarified. Circumstantial evidence from mouse models of pulmonary infections implicates UPAR in the host clearance of the causative bacterial pathogens [30-33]. H. pylori utilizes various host cell surface glycoproteins to anchor to the gastric epithelial cells $[64,65]$. This opens the intriguing possibility that uPAR could play an accessory role in anchoring $H$. pylori to the epithelial cells in vivo via its interplay with integrin function. Future studies scrutinizing this hypothesis experimentally are nevertheless needed.

Although our study provides correlations implying that there is a functional link between UPAR expression and H. pylori infection in vivo, some precaution in the interpretations are required. First, mouse models typically show important intra- and inter-group variations, which is in fact one of the weaknesses inherent to these models. Second, the evidence suggesting a connection between UPAR expression and inflammation is indirect based on correlative observations without direct proof of causality. Notwithstanding this limitation, there is ample evidence in the literature demonstrating a causative effect of uPAR expression on the exacerbation of chronic inflammatory conditions [37,47,54-58].

Supplementary Materials: The following are available online at http://www.mdpi.com/2076-2607/8/7/1019/s1, Figure S1: H. pylori colonization of the mouse stomach at selected time-points, Figure S2: Histology of the murine gastric corpus mucosa three weeks after H. pylori colonization, Figure S3: uPAR expression in distal locations of the gastrointestinal tract and verification of the specificity of uPAR immunohistochemistry, Figure S4: Kinetics of $H$. pylori-induced uPAR expression in the squamo-columnar junction and antrum of the mouse stomach, Figure S5: uPA expression at different anatomical locations of the stomach in unchallenged and $H$. pylori-infected mice, Figure S6: Histopathology of the stomach of unchallenged and H. pylori-infected mice without or with antimicrobial treatment for H. pylori eradication, Figure S7: Histopathology of the stomach of unchallenged and H. pylori-infected mice without or with $\mathrm{PGE}_{2}$ treatment.

Author Contributions: Conceptualization, W.A.-A. and M.P.; methodology, W.A.-A., M.E.S., L.R., M.C.K., M.I., O.D.L., K.A.K., and L.P.A.; formal analysis, W.A.-A., M.P., M.E.S., I.J.C. and O.D.L.; investigation, W.A.-A., M.E.S., 
M.C.K., L.R, I.K.L., M.I., O.D.L. and M.P.; data curation, I.J.C.; writing-original draft preparation, W.A.-A. and M.P.; writing—review and editing, W.A.-A., M.E.S., L.R., M.C.K., I.J.C., I.K.L., M.I., O.D.L., K.A.K., L.P.A. and M.P.; supervision, W.A.-A., O.D.L., K.A.K., L.P.A. and M.P.; project administration, W.A.-A. and M.P.; funding acquisition, W.A.-A., K.A.K., L.P.A. and M.P. All authors have read and agreed to the published version of the manuscript.

Funding: This research was funded by Danish Cancer Society (Grant No. R2-A261-09-S2), Axel Muusfeldts Fond, Krista og Viggo Petersens Fond.

Acknowledgments: We thank Lotte Frederiksen, Gitte Juhl Funch, and John Post for excellent technical assistance.

Conflicts of Interest: The authors declare no conflict of interest. The funders had no role in the design of the study; in the collection, analyses, or interpretation of data; in the writing of the manuscript, or in the decision to publish the results.

\section{References}

1. Correa, P.; Houghton, J. Carcinogenesis of Helicobacter pylori. Gastroenterology 2007, 133, 659-672. [CrossRef]

2. Uemura, N.; Okamoto, S.; Yamamoto, S.; Matsumura, N.; Yamaguchi, S.; Yamakido, M.; Taniyama, K.; Sasaki, N.; Schlemper, R.J. Helicobacter pylori infection and the development of gastric cancer. N. Engl. J. Med. 2001, 345, 784-789. [CrossRef]

3. O'Connor, A.; O'Morain, C.A.; Ford, A.C. Population screening and treatment of Helicobacter pylori infection. Nat. Rev. Gastroenterol. Hepatol. 2017, 14, 230-240. [CrossRef] [PubMed]

4. Kyburz, A.; Müller, A. Helicobacter pylori and Extragastric Diseases. Curr. Top. Microbiol. Immunol. 2017, 400, 325-347. [CrossRef] [PubMed]

5. Taye, B.; Enquselassie, F.; Tsegaye, A.; Amberbir, A.; Medhin, G.; Fogarty, A.; Robinson, K.; Davey, G. Association between infection with Helicobacter pylori and atopy in young Ethiopian children: A longitudinal study. Clin. Exp. Allergy 2017, 47, 1299-1308. [CrossRef] [PubMed]

6. Salama, N.R.; Hartung, M.L.; Müller, A. Life in the human stomach: Persistence strategies of the bacterial pathogen Helicobacter pylori. Nat. Rev. Microbiol. 2013, 11, 385-399. [CrossRef] [PubMed]

7. Wilson, K.T.; Crabtree, J.E. Immunology of Helicobacter pylori: Insights into the failure of the immune response and perspectives on vaccine studies. Gastroenterology 2007, 133, 288-308. [CrossRef] [PubMed]

8. Cover, T.L. Helicobacter pylori Diversity and Gastric Cancer Risk. MBio 2016, 7, e01869-15. [CrossRef]

9. Amieva, M.; Peek, R.M. Pathobiology of Helicobacter pylori-Induced Gastric Cancer. Gastroenterology 2016, 150, 64-78. [CrossRef]

10. Kriegbaum, M.C.; Persson, M.; Haldager, L.; Alpízar-Alpízar, W.; Jacobsen, B.; Gårdsvoll, H.; Kjær, A.; Ploug, M. Rational targeting of the urokinase receptor (uPAR): Development of antagonists and non-invasive imaging probes. Curr. Drug Targets 2011, 12, 1711-1728. [CrossRef]

11. Alpizar-Alpizar, W.; Christensen, I.J.; Santoni-Rugiu, E.; Skarstein, A.; Ovrebo, K.; Illemann, M.; Laerum, O.D. Urokinase plasminogen activator receptor on invasive cancer cells: A prognostic factor in distal gastric adenocarcinoma. Int. J. Cancer 2012, 131, E329-E336. [CrossRef] [PubMed]

12. Brungs, D.; Chen, J.; Aghmesheh, M.; Vine, K.L.; Becker, T.M.; Carolan, M.G.; Ranson, M. The urokinase plasminogen activation system in gastroesophageal cancer: A systematic review and meta-analysis. Oncotarget 2017, 8, 23099-23109. [CrossRef] [PubMed]

13. Lund, I.K.; Illemann, M.; Thurison, T.; Christensen, I.J.; Høyer-Hansen, G. uPAR as anti-cancer target: Evaluation of biomarker potential, histological localization, and antibody-based therapy. Curr. Drug Targets 2011, 12, 1744-1760. [CrossRef] [PubMed]

14. Gårdsvoll, H.; Kjaergaard, M.; Jacobsen, B.; Kriegbaum, M.C.; Huang, M.; Ploug, M. Mimicry of the regulatory role of urokinase in lamellipodia formation by introduction of a non-native interdomain disulfide bond in its receptor. J. Biol. Chem. 2011, 286, 43515-43526. [CrossRef]

15. Madsen, C.D.; Ferraris, G.M.; Andolfo, A.; Cunningham, O.; Sidenius, N. uPAR-induced cell adhesion and migration: Vitronectin provides the key. J. Cell Biol. 2007, 177, 927-939. [CrossRef]

16. Chaurasia, P.; Aguirre-Ghiso, J.A.; Liang, O.D.; Gardsvoll, H.; Ploug, M.; Ossowski, L. A region in urokinase plasminogen receptor domain III controlling a functional association with alpha5beta1 integrin and tumor growth. J. Biol. Chem. 2006, 281, 14852-14863. [CrossRef]

17. Aguirre Ghiso, J.A.; Kovalski, K.; Ossowski, L. Tumor dormancy induced by downregulation of urokinase receptor in human carcinoma involves integrin and MAPK signaling. J. Cell Biol. 1999, 147, 89-104. [CrossRef] 
18. Smith, H.W.; Marshall, C.J. Regulation of cell signalling by uPAR. Nat. Rev. Mol. Cell Biol. 2010, 11, $23-36$. [CrossRef]

19. Persson, M.; Madsen, J.; Østergaard, S.; Jensen, M.M.; Jørgensen, J.T.; Juhl, K.; Lehmann, C.; Ploug, M.; Kjaer, A. Quantitative PET of human urokinase-type plasminogen activator receptor with 64Cu-DOTA-AE105: Implications for visualizing cancer invasion. J. Nucl. Med. 2012, 53, 138-145. [CrossRef]

20. Persson, M.; Skovgaard, D.; Brandt-Larsen, M.; Christensen, C.; Madsen, J.; Nielsen, C.H.; Thurison, T.; Klausen, T.L.; Holm, S.; Loft, A.; et al. First-in-human uPAR PET: Imaging of Cancer Aggressiveness. Theranostics 2015, 5, 1303-1316. [CrossRef] [PubMed]

21. Ploug, M. Structure-driven design of radionuclide tracers for non-invasive imaging of uPAR and targeted radiotherapy. The tale of a synthetic peptide antagonist. Theranostics 2013, 3, 467-476. [CrossRef] [PubMed]

22. Amor, C.; Feucht, J.; Leibold, J.; Ho, Y.J.; Zhu, C.; Alonso-Curbelo, D.; Mansilla-Soto, J.; Boyer, J.A.; Li, X.; Giavridis, T.; et al. Senolytic CAR T cells reverse senescence-associated pathologies. Nature 2020, 583, 127-132. [CrossRef]

23. El-Etr, S.H.; Mueller, A.; Tompkins, L.S.; Falkow, S.; Merrell, D.S. Phosphorylation-independent effects of CagA during interaction between Helicobacter pylori and T84 polarized monolayers. J. Infect. Dis. 2004, 190, 1516-1523. [CrossRef] [PubMed]

24. Guillemin, K.; Salama, N.R.; Tompkins, L.S.; Falkow, S. Cag pathogenicity island-specific responses of gastric epithelial cells to Helicobacter pylori infection. Proc. Natl. Acad. Sci. USA 2002, 99, 15136-15141. [CrossRef] [PubMed]

25. Kim, S.H.; Sierra, R.A.; McGee, D.J.; Zabaleta, J. Transcriptional profiling of gastric epithelial cells infected with wild type or arginase-deficient Helicobacter pylori. BMC Microbiol. 2012, 12, 175. [CrossRef] [PubMed]

26. Sepulveda, A.R.; Tao, H.; Carloni, E.; Sepulveda, J.; Graham, D.Y.; Peterson, L.E. Screening of gene expression profiles in gastric epithelial cells induced by Helicobacter pylori using microarray analysis. Aliment. Pharmacol. Ther. 2002, 16 (Suppl. S2), 145-157. [CrossRef]

27. Kenny, S.; Duval, C.; Sammut, S.J.; Steele, I.; Pritchard, D.M.; Atherton, J.C.; Argent, R.H.; Dimaline, R.; Dockray, G.J.; Varro, A. Increased expression of the urokinase plasminogen activator system by Helicobacter pylori in gastric epithelial cells. Am. J. Physiol. Gastrointest. Liver Physiol. 2008, 295, G431-G441. [CrossRef]

28. Vogel, C.; Marcotte, E.M. Insights into the regulation of protein abundance from proteomic and transcriptomic analyses. Nat. Rev. Genet. 2012, 13, 227-232. [CrossRef]

29. Alpízar-Alpízar, W.; Nielsen, B.S.; Sierra, R.; Illemann, M.; Ramírez, J.A.; Arias, A.; Durán, S.; Skarstein, A.; Ovrebo, K.; Lund, L.R.; et al. Urokinase plasminogen activator receptor is expressed in invasive cells in gastric carcinomas from high- and low-risk countries. Int. J. Cancer 2010, 126, 405-415. [CrossRef]

30. Gyetko, M.R.; Sud, S.; Kendall, T.; Fuller, J.A.; Newstead, M.W.; Standiford, T.J. Urokinase receptor-deficient mice have impaired neutrophil recruitment in response to pulmonary Pseudomonas aeruginosa infection. J. Immunol. 2000, 165, 1513-1519. [CrossRef]

31. Hovius, J.W.; Bijlsma, M.F.; van der Windt, G.J.; Wiersinga, W.J.; Boukens, B.J.; Coumou, J.; Oei, A.; de Beer, R.; de Vos, A.F.; van't Veer, C.; et al. The urokinase receptor (uPAR) facilitates clearance of Borrelia burgdorferi. PLoS Pathog. 2009, 5, e1000447. [CrossRef] [PubMed]

32. Rijneveld, A.W.; Levi, M.; Florquin, S.; Speelman, P.; Carmeliet, P.; van Der Poll, T. Urokinase receptor is necessary for adequate host defense against pneumococcal pneumonia. J. Immunol. 2002, 168, 3507-3511. [CrossRef] [PubMed]

33. Wiersinga, W.J.; Kager, L.M.; Hovius, J.W.; van der Windt, G.J.; de Vos, A.F.; Meijers, J.C.; Roelofs, J.J.; Dondorp, A.; Levi, M.; Day, N.P.; et al. Urokinase receptor is necessary for bacterial defense against pneumonia-derived septic melioidosis by facilitating phagocytosis. J. Immunol. 2010, 184, 3079-3086. [CrossRef] [PubMed]

34. Lee, C.W.; Rickman, B.; Rogers, A.B.; Muthupalani, S.; Takaishi, S.; Yang, P.; Wang, T.C.; Fox, J.G. Combination of sulindac and antimicrobial eradication of Helicobacter pylori prevents progression of gastric cancer in hypergastrinemic INS-GAS mice. Cancer Res. 2009, 69, 8166-8174. [CrossRef]

35. van Zanten, S.J.; Kolesnikow, T.; Leung, V.; O’Rourke, J.L.; Lee, A. Gastric transitional zones, areas where Helicobacter treatment fails: Results of a treatment trial using the Sydney strain mouse model. Antimicrob. Agents Chemother. 2003, 47, 2249-2255. [CrossRef] 
36. Toller, I.M.; Hitzler, I.; Sayi, A.; Mueller, A. Prostaglandin E2 prevents Helicobacter-induced gastric preneoplasia and facilitates persistent infection in a mouse model. Gastroenterology 2010, 138, 1455-1467, 1467.e1451-e1454. [CrossRef]

37. Solberg, H.; Ploug, M.; Høyer-Hansen, G.; Nielsen, B.S.; Lund, L.R. The murine receptor for urokinase-type plasminogen activator is primarily expressed in tissues actively undergoing remodeling. J. Histochem. Cytochem. 2001, 49, 237-246. [CrossRef]

38. Kristensen, P.; Eriksen, J.; Danø, K. Localization of urokinase-type plasminogen activator messenger RNA in the normal mouse by in situ hybridization. J. Histochem. Cytochem. 1991, 39, 341-349. [CrossRef]

39. Illemann, M.; Bird, N.; Majeed, A.; Laerum, O.D.; Lund, L.R.; Danø, K.; Nielsen, B.S. Two distinct expression patterns of urokinase, urokinase receptor and plasminogen activator inhibitor-1 in colon cancer liver metastases. Int. J. Cancer 2009, 124, 1860-1870. [CrossRef]

40. Watson, S.A.; Durrant, L.G.; Wencyk, P.M.; Watson, A.L.; Morris, D.L. Intracellular gastrin in human gastrointestinal tumor cells. J. Natl. Cancer Inst. 1991, 83, 866-871. [CrossRef]

41. Gårdsvoll, H.; Werner, F.; Søndergaard, L.; Danø, K.; Ploug, M. Characterization of low-glycosylated forms of soluble human urokinase receptor expressed in Drosophila Schneider 2 cells after deletion of glycosylation-sites. Protein Expr. Purif. 2004, 34, 284-295. [CrossRef] [PubMed]

42. Wang, T.C.; Goldenring, J.R.; Dangler, C.; Ito, S.; Mueller, A.; Jeon, W.K.; Koh, T.J.; Fox, J.G. Mice lacking secretory phospholipase A2 show altered apoptosis and differentiation with Helicobacter felis infection. Gastroenterology 1998, 114, 675-689. [CrossRef]

43. Rogers, A.B. Histologic scoring of gastritis and gastric cancer in mouse models. Methods Mol. Biol. 2012, 921, 189-203. [CrossRef] [PubMed]

44. Iwamoto, J.; Mizokami, Y.; Takahashi, K.; Nakajima, K.; Ohtsubo, T.; Miura, S.; Narasaka, T.; Takeyama, H.; Omata, T.; Shimokobe, K.; et al. Expressions of urokinase-type plasminogen activator, its receptor and plasminogen activator inhibitor-1 in gastric cancer cells and effects of Helicobacter pylori. Scand. J. Gastroenterol. 2005, 40, 783-793. [CrossRef] [PubMed]

45. Kim, M.H.; Yoo, H.S.; Kim, M.Y.; Jang, H.J.; Baek, M.K.; Kim, H.R.; Kim, K.K.; Shin, B.A.; Ahn, B.W.; Jung, Y.D. Helicobacter pylori stimulates urokinase plasminogen activator receptor expression and cell invasiveness through reactive oxygen species and NF-kappaB signaling in human gastric carcinoma cells. Int. J. Mol. Med. 2007, 19, 689-697.

46. Kim, M.H.; Yoo, H.S.; Chang, H.J.; Hong, M.H.; Kim, H.D.; Chung, I.J.; Shin, B.A.; Cho, M.J.; Ahn, B.W.; Jung, Y.D. Urokinase plasminogen activator receptor is upregulated by Helicobacter pylori in human gastric cancer AGS cells via ERK, JNK, and AP-1. Biochem. Biophys. Res. Commun. 2005, 333, 874-880. [CrossRef]

47. Connolly, B.M.; Choi, E.Y.; Gårdsvoll, H.; Bey, A.L.; Currie, B.M.; Chavakis, T.; Liu, S.; Molinolo, A.; Ploug, M.; Leppla, S.H.; et al. Selective abrogation of the uPA-uPAR interaction in vivo reveals a novel role in suppression of fibrin-associated inflammation. Blood 2010, 116, 1593-1603. [CrossRef]

48. Danø, K.; Behrendt, N.; Høyer-Hansen, G.; Johnsen, M.; Lund, L.R.; Ploug, M.; Rømer, J. Plasminogen activation and cancer. Thromb. Haemost. 2005, 93, 676-681. [CrossRef]

49. Heiss, M.M.; Allgayer, H.; Gruetzner, K.U.; Funke, I.; Babic, R.; Jauch, K.W.; Schildberg, F.W. Individual development and uPA-receptor expression of disseminated tumour cells in bone marrow: A reference to early systemic disease in solid cancer. Nat. Med. 1995, 1, 1035-1039. [CrossRef]

50. Croxen, M.A.; Sisson, G.; Melano, R.; Hoffman, P.S. The Helicobacter pylori chemotaxis receptor TlpB (HP0103) is required for $\mathrm{pH}$ taxis and for colonization of the gastric mucosa. J. Bacteriol. 2006, 188, 2656-2665. [CrossRef]

51. Schreiber, S.; Konradt, M.; Groll, C.; Scheid, P.; Hanauer, G.; Werling, H.O.; Josenhans, C.; Suerbaum, S. The spatial orientation of Helicobacter pylori in the gastric mucus. Proc. Natl. Acad. Sci. USA 2004, 101, 5024-5029. [CrossRef] [PubMed]

52. Falk, P.; Roth, K.A.; Borén, T.; Westblom, T.U.; Gordon, J.I.; Normark, S. An in vitro adherence assay reveals that Helicobacter pylori exhibits cell lineage-specific tropism in the human gastric epithelium. Proc. Natl. Acad. Sci. USA 1993, 90, 2035-2039. [CrossRef] [PubMed]

53. Hessey, S.J.; Spencer, J.; Wyatt, J.I.; Sobala, G.; Rathbone, B.J.; Axon, A.T.; Dixon, M.F. Bacterial adhesion and disease activity in Helicobacter associated chronic gastritis. Gut 1990, 31, 134-138. [CrossRef] 
54. Rømer, J.; Lund, L.R.; Eriksen, J.; Pyke, C.; Kristensen, P.; Danø, K. The receptor for urokinase-type plasminogen activator is expressed by keratinocytes at the leading edge during re-epithelialization of mouse skin wounds. J. Invest. Dermatol. 1994, 102, 519-522. [CrossRef]

55. Laerum, O.D.; Illemann, M.; Skarstein, A.; Helgeland, L.; Ovrebø, K.; Danø, K.; Nielsen, B.S. Crohn's disease but not chronic ulcerative colitis induces the expression of PAI-1 in enteric neurons. Am. J. Gastroenterol. 2008, 103, 2350-2358. [CrossRef]

56. Busso, N.; Péclat, V.; So, A.; Sappino, A.P. Plasminogen activation in synovial tissues: Differences between normal, osteoarthritis, and rheumatoid arthritis joints. Ann. Rheum. Dis. 1997, 56, 550-557. [CrossRef] [PubMed]

57. Thornton, S.; Raghu, H.; Cruz, C.; Frederick, M.D.; Palumbo, J.S.; Mullins, E.S.; Almholt, K.; Usher, P.A.; Flick, M.J. Urokinase plasminogen activator and receptor promote collagen-induced arthritis through expression in hematopoietic cells. Blood Adv. 2017, 1, 545-556. [CrossRef]

58. Almholt, K.; Hebsgaard, J.B.; Nansen, A.; Andersson, C.; Pass, J.; Rønø, B.; Thygesen, P.; Pelzer, H.; Loftager, M.; Lund, I.K.; et al. Antibody-Mediated Neutralization of uPA Proteolytic Function Reduces Disease Progression in Mouse Arthritis Models. J. Immunol. 2018, 200, 957-965. [CrossRef]

59. Cai, X.; Carlson, J.; Stoicov, C.; Li, H.; Wang, T.C.; Houghton, J. Helicobacter felis eradication restores normal architecture and inhibits gastric cancer progression in C57BL/6 mice. Gastroenterology 2005, 128, 1937-1952. [CrossRef]

60. Karam, S.M.; Leblond, C.P. Dynamics of epithelial cells in the corpus of the mouse stomach. II. Outward migration of pit cells. Anat. Rec. 1993, 236, 280-296. [CrossRef]

61. Lee, A.; O’Rourke, J.; De Ungria, M.C.; Robertson, B.; Daskalopoulos, G.; Dixon, M.F. A standardized mouse model of Helicobacter pylori infection: Introducing the Sydney strain. Gastroenterology 1997, 112, 1386-1397. [CrossRef]

62. Crabtree, J.E.; Ferrero, R.L.; Kusters, J.G. The mouse colonizing Helicobacter pylori strain SS1 may lack a functional cag pathogenicity island. Helicobacter 2002, 7, 139-140; [CrossRef] [PubMed]

63. Eaton, K.A.; Kersulyte, D.; Mefford, M.; Danon, S.J.; Krakowka, S.; Berg, D.E. Role of Helicobacter pylori cag region genes in colonization and gastritis in two animal models. Infect. Immun. 2001, 69, 2902-2908. [CrossRef]

64. Ilver, D.; Arnqvist, A.; Ogren, J.; Frick, I.M.; Kersulyte, D.; Incecik, E.T.; Berg, D.E.; Covacci, A.; Engstrand, L.; Borén, T. Helicobacter pylori adhesin binding fucosylated histo-blood group antigens revealed by retagging. Science 1998, 279, 373-377. [CrossRef]

65. Mahdavi, J.; Sondén, B.; Hurtig, M.; Olfat, F.O.; Forsberg, L.; Roche, N.; Angstrom, J.; Larsson, T.; Teneberg, S.; Karlsson, K.A.; et al. Helicobacter pylori SabA adhesin in persistent infection and chronic inflammation. Science 2002, 297, 573-578. [CrossRef] [PubMed]

(C) 2020 by the authors. Licensee MDPI, Basel, Switzerland. This article is an open access article distributed under the terms and conditions of the Creative Commons Attribution (CC BY) license (http://creativecommons.org/licenses/by/4.0/). 